\title{
Effects of wind strength and wave height on ship incident risk: regional trends and seasonality
}

\author{
Christiaan Heij ${ }^{1}$, Sabine Knapp ${ }^{2}$ \\ Econometric Institute, Erasmus University Rotterdam \\ Econometric Institute Report 2014-15
}

\begin{abstract}
Oceanographic conditions like wind strength and wave height affect the risk of shipping incidents. Seasonal variations and trends in these effects are studied for weather-related incidents and pollution incidents, for six major ship types and for six regions across the globe. The employed database of more than five million observations combines information from various sources on oceanographic conditions, ship particulars, and incidents. The magnitude of wind and wave effects is found to vary by ship type, region, season, and period, and most of these effects are larger during autumn and winter season and in recent periods.
\end{abstract}

\section{Keywords}

shipping incident, pollution, oceanographic risk factors, sample selection bias

\footnotetext{
${ }^{1}$ Econometric Institute, Erasmus School of Economics, Erasmus University Rotterdam, P.O. Box 1738, NL 3000 DR Rotterdam, The Netherlands; corresponding author, phone +31-10-4081264, fax: +31-10-4089162, email heij@ese.eur.nl

${ }^{2}$ Econometric Institute, Erasmus School of Economics, Erasmus University Rotterdam, P.O. Box 1738, NL 3000 DR Rotterdam, The Netherlands; email knapp@ese.eur.nl Disclaimer for Knapp: The views expressed in this article represent those of the author and do not necessarily represent those of the Australian Maritime Safety Authority (AMSA).
} 


\section{Introduction}

Many maritime administrations and coastal states are nowadays trying to become more proactive in their risk mitigation strategies. Current maritime risk assessments often still ignore various risk dimensions and associated uncertainties (Merrick and Van Dorp, 2006). Van der Hoorn and Knapp (2014) propose a multi-layered approach to incorporate shipspecific risk, vessel traffic densities, and location-specific conditions such as bathymetry, wind, waves, currents, and coastal sensitivities to pollution.

For the North Atlantic, it has been reported that oceanographic conditions are changing, with rising sea levels, larger wave height and wind strength, changing wind patterns, and increasing frequency and force of storms (Wolf and Challenor, 2002; Tsimplis et al., 2005; European Parliament, 2007; IPCC, 2007). Meanwhile, new shipping routes are opening up, for example, due to the melting Arctic. Such developments necessitate investigation of the relation between oceanographic conditions and maritime safety, including vessel design aspects like stability and long-term wave stress on the hull structure (IMO, 1995, 2005a, 2005b). Knapp et al. (2011) study the effect of wind strength and wave height on the risk of weather-related incidents for the North Atlantic. The current paper extends this type of risk evaluation to a global level and evaluates risk of weather-related incidents and pollution incidents for six regions across the globe. The focus is on seasonal effects and trends (changes over time) in wind speed and wave height with their impact on incident risk for the following six regions: North Atlantic; East Africa and Indian Ocean; Japan, Korea, and South Chinese Sea; South Atlantic and West Africa; North Pacific; South Pacific and Antarctica. Other relevant physical factors, such as directions of wind and waves and the strength and direction of currents, are not available in the database and are therefore not included in the analysis.

\section{Data}

\subsection{Data sources}

The employed dataset has been compiled from various sources and contains information on a list of variables, including observation date and location (latitude and longitude), ship type, ship particulars (including histories), oceanographic conditions (wind speed and wave height), and incident information (yes or no, and if yes, of which type). The analysis period runs from January 1979 to December 2008. This is a relatively short period to analyze trends in 
oceanographic conditions, but it is very hard to obtain ship histories on inspections and changes of ship particulars prior to 1979.

The incident data are obtained from different sources, including HIS-Maritime (former Lloyd's Register Fairplay), Lloyd's Maritime Intelligence Unit, and the International Maritime Organization (IMO). As casualty definitions differ widely among these data providers, the casualty types are manually reclassified according to IMO definitions (IMO, 2000). For each incident, we identify whether it is related to weather conditions. We focus on pollution incidents, irrespective of their seriousness, and on weather-related incidents, which cover the following categories: flooding, foundering, capsizing, hull related failures, wrecked, stranded, and grounded. Apart from the type of incident, these data carry also information on date, location, and the vessel that is involved in the incident. Since there is no information on the precise location and oceanographic conditions for the incident data, we use average values for the available non-incident data on wind speed and wave height that apply for the specific day and for the specific area of the incident.

Information on ship particulars has been obtained from IHS Maritime. We consider the following six ship types, since the safety qualities vary across these types (Knapp and Franses, 2007): general cargo vessels, dry bulk carriers, container ships, tankers, passenger ships, and other vessels. The ship particulars include age and tonnage of the vessel, as well as its classification society (International Association of Classification Societies IACS, nonIACS, or undefined), its flag state (black, grey, white, or undefined, according to the Paris Memoranda of Understanding flag list), and changes in flag, beneficial owner, and Document of Compliance company (responsible for safety management) in the year prior to the observation. Data on ship economic cycles come from Shipping Intelligence Network and Clarksons Research to reflect market conditions that influence vessel safety quality (Bijwaard and Knapp, 2009).

A proxy for vessel safety quality consists of ship-specific inspection histories, including the total number of detentions and deficiencies. Sources for this type of information are various port-state control regimes, industry inspections from RightShip, the Chemical Distribution Institute, and the Oil Companies International Marine Forum, flag state inspections from various flag states, and ISM audits. The historical information also covers changes of ship particulars over time, such as changes in ownership, flag, or classification society. 
Oceanographic data and vessel positions are obtained from the International Comprehensive Ocean-Atmosphere Data Set (ICOADS), which used to be the largest compilation of surface meteorological observations based on the Voluntary Observing Ships (VOS). The dataset is characterized by varying reporting frequencies at the individual ship level as well as across regions, ranging from many times a day to only once in many days. The data are grouped into six regions based on the Marsden Grid, which divides the world map into grid cells with sizes of ten degrees latitude by ten degrees longitude. The wind and wave data are corrected as suggested by Thomas et al. (2005) and Gulev and Grigorieva (2006) to prevent biases due to multiple measurement techniques. To reduce the over-representation of vessels with high reporting frequency, the oceanographic data are aggregated so that (at most) a single observation remains per vessel per day per Marsden grid cell.

The resulting database contains about 5.5 million observations, which are summarized per region and ship type in Appendix A. Most observations are available for the following three regions: North Atlantic; Japan, Korea, and South Chinese Sea; North Pacific. In the database, the first two of these regions have the far majority of weather-related and pollution incidents, which are relatively scarce for all other four regions. These findings are biased because underreporting frequencies of incidents vary across regions, and these and other sample selection issues are discussed in Section 3. The majority of both weather-related and pollution type incidents are available for general cargo vessels and for tankers, with fewer data for dry bulk and much fewer for container ships, passenger ships, and other vessel types. The majority of incidents in the database occurred during the autumn and winter season.

\subsection{Trends and seasonality}

Figures 1 and 2 provide an idea per region of overall trends and seasonality in wind speed (in kilometer per hour) and wave height (significant wave height in meter). Figure 1 shows the sample mean and standard deviation of wind speed and wave height for four sub-samples of the data, that is, for two periods (1979-1991 and 1992-2008) and for two seasons (autumn and winter, defined as October-March for the three regions on the northern hemisphere and AprilSeptember for the other three regions on the southern hemisphere, and the complementary spring and summer season). In all regions, the average wind speed and wave height are higher in the autumn and winter season. The average wind speed and wave height are considerably higher for the second period, for both seasons. The North Atlantic and the North Pacific have 
relatively the highest mean values, and the South Atlantic and West Africa the lowest. The variation in wind speed and wave height is the highest in the spring and summer season during 1992-2008 and lowest in the autumn and winter season during 1979-1991. The North Atlantic and the North Pacific show most variation, and the South Atlantic and West Africa show least variation. The latter result may be partly because this region has parts on both hemispheres, so that mean levels and variations are smoothed out somewhat.

Figure 2 is based on the sub-sample of observations that apply for tankers. Wind speed and wave height show clear seasonal fluctuations, with peaks in the autumn and winter season. Incident risk, measured as the fraction of incident observations in the database, has higher values for both weather-related and pollution incidents during the autumn and winter season. Such seasonal comparisons within a given region are valid, because the available data samples are biased across regions and time (see Section 3), but not across seasons.

$<<$ Figures 1 and 2 to be inserted about here. $>>$

\section{Methodology}

\subsection{Model structure}

We employ (binary regression) logit models to relate the probability of an incident to a set of risk factors, including wind speed and wave height. As the effect of these factors on vessel safety differs among ship types, the logit models are estimated separately for each of the six ship types. For each ship type, we analyze the presence and nature of region-specific short-run seasonal effects (winter and autumn versus spring and summer) and long-run trend effects (period 1979-1991 versus 1992-2008). As incident observations are relatively scarce (see Table A.1), it is not possible to make a full split-up of the effects per region, season, and period, as this would require 48 coefficients for wind and wave. We therefore specify two types of model, one with seasonal effects and without trends, and the other with trend effects and without seasonality. This gives in total twelve models for weather-related incidents, that is, for each ship type a seasonal model and a trend model. For pollution, we estimate both types of model only for general cargo vessels, dry bulk carriers, and tankers, because pollution incidents are too scarce for the other three ship types (see Table A.1). 
Each logit model contains the following list of ship-specific risk factors: age; tonnage; classification society; flag state; changes in flag, owner, and Document of Compliance company; flag state inspections; ISM audits; number of detentions and deficiencies of port state control inspections. Ship economic cycles are also included. Further, the seasonal model contains twelve coefficients for wind speed, that is, for each region two coefficients, one for the autumn and winter season and the other for the spring and summer season. The same applies for wave height. The trend model contains also twelve coefficients for both wind speed and wave height, with two coefficients for each region, one for the period 1979-1991 and the other for 1992-2008.

\subsection{Sample selection effects}

Some additional variables are needed in the specification of the logit models, because the sampling conditions of both incidents and non-incidents vary across regions and time. The quality of incident data, that is, the fraction of actual incidents that are reported and that are present in the database, varies both across regions and over time. Further, the non-incident data depend on VOS participation rates, which vary per region and which have declined over time, as well as on the frequency of reports of VOS vessels. The last type of heterogeneity has been reduced by aggregating data for vessels that report more than once a day to a single daily observation, but other vessels report less than once a day or at irregular frequencies. For given region and given time period, there are no evident sampling differences across seasons, so that risk comparisons across seasons (as in Figure 2) are somewhat easier than across time.

Franses and Paap (2001, pp. 73-75) show that logit models have the attractive property that under-reporting of non-incidents affects only the intercept term (the baseline risk) and not the slope parameters, provided that the selection mechanism does not depend on the risk factors. The marginal effect of risk factors is therefore still estimated correctly, but not the risk levels. To obtain risk levels, the intercept term should be corrected by $\log \left(f_{0}\right)$, where $\log$ denotes the natural logarithm and $f_{0}$ is the fraction of real-world non-incidents available in the database. This result can easily be generalized to the situation where also the incidents are underreported, with correction term $\log \left(f_{0} / f_{1}\right)$ where $f_{1}$ is the fraction of real-world incidents available in the database.

The sample selectivity is more complicated for the data at hand, as it varies across regions and time with unknown selection fractions $f_{0}$ and $f_{1}$. The above result implies that risk levels 
cannot be estimated in this case, but the marginal effect of risk factors can still be estimated correctly (that is, consistently) if the models are estimated separately per region and per time period. Such a split-up is undesirable for the current application, as the number of incidents per region per time period is small (see Table A.1), leading to large efficiency losses. We therefore employ the following strategy. First we estimate twelve models, one per region and time period, to get consistent (but inefficient) estimates of all slope parameters. Next, we estimate a single model for all regions and both time periods combined, with twelve level dummies, one for each region and time period, and with region and period (or season) specific wind and wave parameters. We then check whether the twelve obtained coefficients of each risk factor (apart from wind and wave) are reasonably similar to the coefficient in the combined model, in the sense that their sign is the same across significant values. If so, we use the combined model with twelve level dummies in order to improve consistency without fear to introduce notable bias. These level dummies are essential to prevent biases in the slope parameters, as is illustrated by the following example. Suppose that regions A and B are actually equally risky and that a given risk factor actually has the same, positive risk effect in both regions. Assume further that the sample selection ratio $\left(f_{0} / f_{1}\right)$ for region $\mathrm{A}$ is twice as high as that for region $\mathrm{B}$. Then region $\mathrm{A}$ has relatively more non-incident data, and region $\mathrm{B}$ artificially appears to be twice as risky as region A. Inclusion of regional dummies guarantees that such artificial risk inflation is absorbed in the baseline risk (dummy coefficient) for region $\mathrm{B}$, instead of wrongly concluding that the risk factor has larger effects in region $\mathrm{B}$ than in region $\mathrm{A}$.

The results reported in Section 4 are all obtained from combined models, because the sign restriction is satisfied rather well. As an illustration, the logit models for weather-related incidents for general cargo vessels contains sixteen risk factors (apart from wind and wave), with effects estimated in twelve specific models and one combined model. Of the resulting sixteen sets of twelve coefficients each, the sign of only two coefficients (about $2 \%$ ) differed

significantly (at $5 \%$ level) from that in the combined model. Similar results apply for other ship types and for pollution incidents.

\subsection{Estimated models}

Summarizing the above, the estimated logit models are of the following type. For each observation in the database, let $y=1$ in case of an incident and $y=0$ in case of no incident, and let $x=\left(x_{1}, \ldots, x_{\mathrm{k}}\right)$ be the collection of risk factors apart from wind speed (WS) and wave 
height $(\mathrm{WH})$. The logit model states that $\operatorname{Prob}(y=1)=\exp (x \beta+z \gamma+d \delta) /(1+\exp (x \beta+z \gamma+$ $d \delta)$ ), where exp denotes the exponential function and $x \beta=\sum x_{\mathrm{i}} \beta_{\mathrm{i}}$. Further, the level dummies are $d \delta=\sum d_{\mathrm{j}} \delta_{\mathrm{j}}$ where $d=\left(d_{1}, \ldots, d_{12}\right)$ are the twelve dummies indicating the region and period. The risk factors of interest are $z \gamma=\mathrm{WS} \times\left(\sum d_{\mathrm{j}} \gamma_{\mathrm{WS}, \mathrm{j}}\right)+\mathrm{WH} \times\left(\sum d_{\mathrm{j}} \gamma_{\mathrm{WH}, \mathrm{j}}\right)$ for the trend model, and $z \gamma=\mathrm{WS} \times\left(\sum D_{\mathrm{j}} \gamma_{\mathrm{WS}, \mathrm{j}}\right)+\mathrm{WH} \times\left(\sum D_{\mathrm{j}} \gamma_{\mathrm{WH}, \mathrm{j}}\right)$ for the seasonality model, where $D=\left(D_{1}\right.$, $\left.\ldots, D_{12}\right)$ are the twelve dummies indicating the region and season. The unknown values of the parameters $(\beta, \gamma, \delta)$ are estimated from the available values of $(y, x, z, d)$ in the database. Because of sample selectivity, the baseline values $\delta$ have no direct interpretation and do not reflect risk levels.

Our analysis focuses on the values of $\gamma$, that is, the region-specific seasonal and trend parameters of wind and wave. More detailed model results can be obtained from the authors upon request. All logit models are estimated by quasi-maximum likelihood to get robust standard errors. Some caution is needed when interpreting standard errors, as these should in principle be corrected for data selectivity. For the current application, selectivity of the nonincident data is believed to be more substantial than that of the incident data. We partly corrected for underreporting of incidents by combining different incident data sources, whereas the share of VOS participating vessels in the world fleet is rather small and has declined from about $10 \%$ in 1979 to about $5 \%$ in 2008 . This situation (with $f_{0} / f_{1}<1$ ) may lead to under-estimation of standard errors, which diminishes for larger samples. As the sample sizes are large for the current application, the amount of bias in reported standard errors will be relatively small. To account for uncertainty in standard errors, we will perform significance tests at the $1 \%$ level (instead of the more conventional 5\% level).

\section{Results}

\subsection{Weather-related incidents}

The methodology described in the previous section is applied for each of the six ship types separately. Table 1 shows the results for regional-specific seasonal effects of wind speed and wave height on the risk for weather-related incidents. Instead of reporting the logit coefficients, the table shows relative risk effects. More precisely, the numbers in the table show the percentage increase in the odds of weather-related incidents if wind speed or wave height increases by one standard deviation (specific per region and per season). Figure 1 shows that this corresponds to increases in wind speed by about 10-15 kilometer per hour and 
in wave height by about $1.5-2.5$ meters. If $c$ is the logit coefficient and $s$ is the standard deviation, then an increase of the risk factor by $s$ implies that the odds is multiplied by $\exp (c \times s)$, where exp is the exponential function. The reported percentage increase in odds is equal to $100 *(\exp (c \times s)-1)$. As the incident risk $p$ is small, the odds $p /(1-p)$ is nearly equal to the incident risk, so that the reported numbers are approximately equal to the percentage increase in the probability of an incident. For example, Table 1 shows that one standard deviation increase in wind speed increases the odds of weather-related incidents for general cargo vessels during autumn and winter in the North Atlantic by $44.3 \%$. If the daily baseline risk for these incidents would be, say, $0.010 \%$, then the increased wind level would cause an increase of the daily risk by about $0.004 \%$ to $0.014 \%$.

Most of the effects in Table 1 are positive, which is in line with the intuitive idea that heavier wind and higher waves impose higher strain on vessel and crew and hence increase the risk for an incident. Wind speed has 22 significant effects of which 21 are positive, and wave height has 30 significant effects of which 25 are positive. Wind effects are relatively large (roughly from $20-40 \%$ ) for most ship types in the North Atlantic and during autumn and winter in the region Japan, Korea, and South Chinese Sea. When all regions are combined, wind effects are stronger in autumn and winter as compared to spring and summer, with differences of about $30 \%$ for general cargo, $15 \%$ for dry bulk, $20 \%$ for tankers, $15 \%$ for passenger vessels, and $25 \%$ for other ship types. Wave effects show somewhat less differences across regions and seasons, possibly also because wave direction has not been taken into account as this information is missing in ICOADS.

$<<$ Table 1 to be inserted about here. $>>$

Table 1 shows also whether or not the effects are stronger in the autumn and winter season. For wind speed, this applies in all 17 cases, whereas for wave height this applies in 11 out of 22 cases. Some caution is needed in interpreting these results, for the following four reasons. First, the models incorporate region-specific baseline dummies to account for sample selection biases. As average wind strength and wave height vary across regions, see Figure 1, part of these oceanographic differences are caught up in the regional baseline effects. Second, the effects reported in Table 1 and in later tables all concern partial effects, so that all other risk factors are assumed to remain constant. Wind and wave are actually quite strongly correlated, with regional correlations ranging from 0.32 for the South Atlantic and West 
Africa to 0.51 for the North Pacific. Third, as stated before, we are not able to incorporate the effect of wind and wave directions, which can vary substantially depending on tide, currents, and bathymetry. Fourth, smaller or even negative coefficients for wind and wave can reflect that high-risk vessels avoid adverse weather conditions. In this case, only relatively safe vessels travel through high wind and wave conditions, so that incident risk may then be lower as compared to good weather conditions when ships of lower safety levels are also trading.

Table 2 is similar in structure to Table 1, and we now consider whether the effects of wind strength and wave height have changed over time. Again, most effects are positive, as expected; 23 out of 25 are positive for wind speed, and 28 out of 31 for wave height. When comparing recent years (1992-2008) with the farther past (1979-1991), the effects are stronger for wind speed in 13 out of 18 cases and for wave height in 12 out of 23 cases. Again, the largest effects for wind speed (roughly from 20-50\%) are found for the North Atlantic and during autumn and winter in the region Japan, Korea, and South Chinese Sea. When all regions are combined, wind effects have become stronger in recent years than in the farther past, by about $10 \%$ for general cargo, $20 \%$ for passenger vessels, and $25 \%$ for other ship types. Wave effects are more varied across ship types and show less differences between the two periods.

$<<$ Table 2 to be inserted about here. $>>$

\subsection{Pollution incidents}

The results for pollution incidents of general cargo vessels, dry bulk carriers, and tankers are in Table 3. The majority of wind and wave effects are positive. In the model for seasonal effects, 10 out of 11 wind effects are positive and 9 out of 10 wave effects are positive. In the model for trend effects, all 10 wind effects and 13 out of 16 wave effects are positive. As compared to spring and summer, the effects are stronger in autumn and winter in 6 out of 8 cases for wind and in 3 out of 7 cases for wave. Further, recent years show stronger wind effects for 3 out of 7 cases and stronger wave effects for 7 out of 11 cases. The strongest wind effects are found for general cargo. For tankers, wind effects are found mostly for the North Atlantic, and wave effects vary across regions. Most consistent positive pollution risk effects of wind and wave are found for general cargo, due to the relatively large amount of observations for this ship type (see Table A.1). Table 3 shows that no significant effects are found for many combinations of ship type, region, and period. This is partially due to the 
relatively small number of pollution incidents, but also because of the absorption of regional and period differences in the region and period dummies that were needed to account for sample selection biases.

$<<$ Table 3 to be inserted about here. $>>$

\section{Conclusions}

The analysis of relations between oceanographic conditions and ship safety involves the challenge to integrate information from various sources. In the databases that we were able to compile, the incident data lack location and oceanographic information at the time of the incident, the oceanographic data lack incident information, and both lack ship-particular information. We merged data from various databases, we reduced sample bias were possible, and we developed a methodology to cope with sample selection effects that differ across regions and time. Wind speed and wave height tend to have higher values in recent years and during the autumn and winter season. Increases in wind strength and in adverse weather conditions have been reported in the literature for the North Atlantic and have been attributed to climate change. The IMO recognizes these developments and is currently dealing with various measures to mitigate risk. Larger wind speed and higher waves increase the risk for weather-related incidents and pollution incidents. The effect sizes vary across regions, seasons, and time. The estimated risk effects can be used to simulate ship-specific safety consequences in scenarios for future wind speeds and wave heights.

The results derived from our database are still far from complete. A deeper investigation of potential climate change effects on shipping safety requires better databases. It would in particular be helpful to build consistent databases containing high frequency observations on refined location grids, including information on oceanographic conditions, passing vessels and their characteristics, and incidents. Recently, automated information system (AIS) data have become available that can be helpful in reducing non-incident sample biases, and further improvements of incident data by IMO will reduce underreporting biases of incidents. 


\section{Acknowledgments}

We thank the data providers, in particular IHS Maritime (former Lloyd's Register Fairplay), and we thank Scott Woodruff from ICOADS and Elizabeth Kent from NOCS for their assistance in understanding the ICOADS data set.

\section{References}

Bijwaard, G., Knapp, S., 2009. Analysis of ship life cycles - the impact of economic cycles and ship inspections. Marine Policy 33, 350-369.

European Parliament, 2007. European Parliament resolution on a future maritime policy for the European Union: a European vision for the oceans and seas, resolution of July 12, 2007.

Franses, P.H., Paap, R., 2001. Quantitative Models in Marketing Research. Cambridge, Cambridge University Press.

Gulev, S., Grigorieva, V., 2006. Variability of the winter wind waves and swell in the North Atlantic and North Pacific as revealed by the Voluntary Observing Ship data. Journal of Climate 19, 5667-5685.

International Maritime Organization, 1995. Code on intact stability for all types of ships covered by IMO instruments, London, IMO.

International Maritime Organization, 2000. MSC/Circ. 953, MEPC/Circ. 372, Reports on marine casualties and incidents, revised harmonized reporting procedures, London, IMO.

International Maritime Organization, 2005a. MSC 80/Inf.4, Goal-based new ship construction standards, response of ship's structure to waves in different sea areas, London, IMO.

International Maritime Organization, 2005b. MSC 80/Inf.3, Goal-based new ship construction standards, safety factors and safety margins, London, IMO.

Intergovernmental Panel on Climate Change, 2007. Climate Change 2007: The Physical Science Basis, Summary for Policymakers, Cambridge, Cambridge University Press.

Knapp, S., Franses, P.H., 2007. Econometric analysis on the effect of port state control inspections on the probability of casualty. Marine Policy 31, 550-563. 
Knapp, S., Kumar, S., Sakurada, Y., Shen, J., 2011. The effect of changes in wind strength and wave heights on the safety of vessels in shipping. Accident Analysis and Prevention 43, $1252-1266$.

Merrick, J.R.W., Van Dorp, R., 2006. Speaking the truth in maritime risk assessment. Risk Analysis 26, 223-237.

Thomas, B.G., Kent, E., Swail, R.V., 2005. Methods to homogenize wind speeds from ships and buoys. International Journal of Climatology 25, 979-995.

Tsimplis, M.N., Woolf, D.K., Osborn, T.J., Wakelin, S., Wolf, J., Flather, R., Shaw, A.G.P.,

Woodworth, P., Challenor, P., Blackman, D., Pert, F., Yan, Z., Jevrejeva, S., 2005. Towards a vulnerability assessment of the UK and northern European coasts: the role of regional climate variability. Philosophical Transactions of the Royal Society A 363, 1329-1358.

Van der Hoorn, S., Knapp, S., 2014. A multi-layered risk exposure assessment approach for the shipping industry. Econometric Institute Report 2014-14, Erasmus University Rotterdam.

Woolf, D.K., Challenor, P.G., 2002. Variability and predictability of the North Atlantic wave climate. Journal of Geophysical Research 107, 9-1 - 9.14.

\section{Appendix A: Number of incidents and non-incidents, per ship type and region}

$<<$ Table A.1 to be inserted here. $>>$ 
Figure 1: Statistics for wind speed (top row) and wave height (bottom row), mean (left column ) and standard deviation (right column) per period ( 1 and 2 for spring and summer in respectively 1979-1991 and 1992-2008, and 3 and 4 for autumn and winter in respectively 1979-1991 and 1992-2008), all obtained from combined database for all six ship types; regions are denoted by 1 for N. America, 2 for E. Africa and Indian Ocean, 3 for Japan, Korea, China, 4 for S. Atlantic and W. Africa, 5 for N. Pacific, and 6 for S. Pacific and Antarctica.
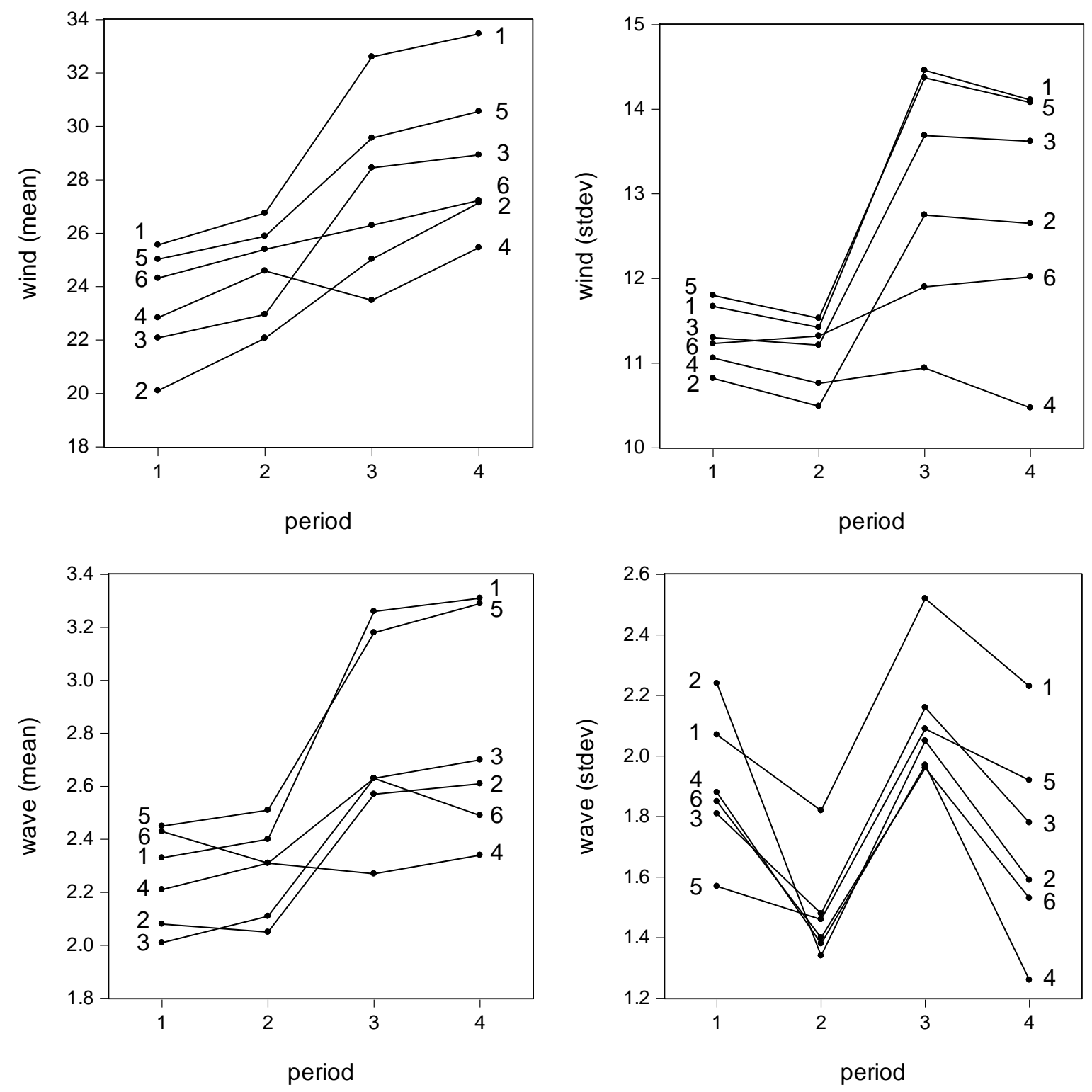
Figure 2: Mean monthly wind speed (top row), mean monthly wave height (middle row), and mean risk for weather-related and pollution incidents per season (bottom row, scaled to have value 1 for season 1, i.e., spring and summer, and season 2 is for autumn and winter), all obtained from tanker database; regions in northern hemisphere are denoted by 1 for $\mathrm{N}$. America, 3 for Japan, Korea, China, and 5 for N. Pacific, and those in southern hemisphere by 2 for E. Africa and Indian Ocean, 4 for S. Atlantic and W. Africa, and 6 for S. Pacific and Antarctica.
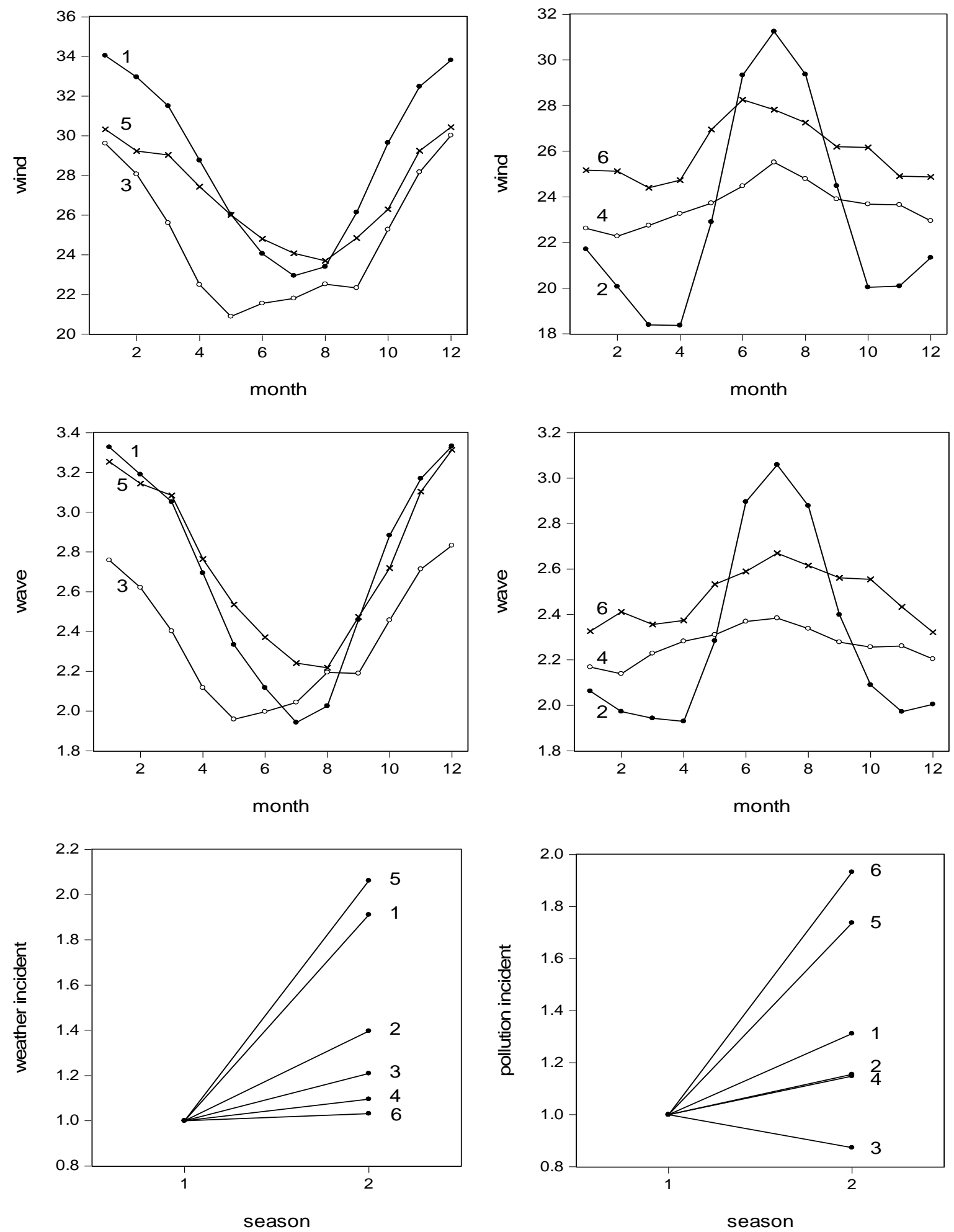
Table 1: Seasonal effects of wind and wave on the risk of weather-related incidents, per ship type and region

\begin{tabular}{|c|c|c|c|c|c|c|c|c|c|c|c|c|c|}
\hline \multirow[t]{2}{*}{ Region } & \multirow[t]{2}{*}{ Season } & \multicolumn{12}{|c|}{ Ship type } \\
\hline & & Cargo & & Dry bulk & & Container & & Tanker & & Passenger & & Other & \\
\hline \multicolumn{14}{|l|}{ Wind } \\
\hline \multirow[t]{2}{*}{ N. Atlantic } & S\&S & 6.4 & & $\mathrm{x}$ & & $\mathrm{x}$ & & 12.4 & & 14.2 & & $\mathrm{x}$ & \\
\hline & $\mathrm{A} \& W$ & 44.3 & + & 21.6 & + & $\mathrm{x}$ & & 30.0 & + & 31.6 & + & 34.7 & + \\
\hline \multirow[t]{2}{*}{ E. Africa, Indian Ocean } & S\&S & $\mathrm{x}$ & & $\mathrm{x}$ & & $\mathrm{x}$ & & -20.4 & & $\mathrm{x}$ & & $\mathrm{x}$ & \\
\hline & $\mathrm{A} \& W$ & 29.8 & + & $\mathrm{x}$ & & $\mathrm{x}$ & & $\mathrm{x}$ & + & $\mathrm{x}$ & & $\mathrm{x}$ & \\
\hline \multirow[t]{2}{*}{ Japan, Korea, S. Chinese Sea } & S\&S & 16.8 & & $\mathrm{x}$ & & $\mathrm{x}$ & & $\mathrm{x}$ & & $\mathrm{x}$ & & $\mathrm{x}$ & \\
\hline & $\mathrm{A} \& W$ & 31.7 & + & 14.5 & + & $\mathrm{x}$ & & 18.3 & + & 30.1 & + & $\mathrm{x}$ & \\
\hline \multirow[t]{2}{*}{ S. Atlantic, W. Africa } & S\&S & $\mathrm{x}$ & & $\mathrm{x}$ & & $\mathrm{x}$ & & $\mathrm{x}$ & & $\mathrm{x}$ & & $\mathrm{x}$ & \\
\hline & $\mathrm{A} \& W$ & $\mathrm{x}$ & & $\mathrm{x}$ & & $\mathrm{x}$ & & $\mathrm{x}$ & & $\mathrm{x}$ & & $\mathrm{x}$ & \\
\hline \multirow[t]{2}{*}{ N. Pacific } & S\&S & -25.7 & & $\mathrm{x}$ & & $\mathrm{x}$ & & $\mathrm{x}$ & & $\mathrm{x}$ & & $\mathrm{x}$ & \\
\hline & $\mathrm{A} \& W$ & $\mathrm{x}$ & + & $\mathrm{x}$ & & $\mathrm{x}$ & & $\mathrm{x}$ & & $\mathrm{x}$ & & $\mathrm{x}$ & \\
\hline \multirow[t]{2}{*}{ S. Pacific, Antarctica } & S\&S & $\mathrm{x}$ & & $\mathrm{x}$ & & $\mathrm{x}$ & & $\mathrm{x}$ & & $\mathrm{x}$ & & $\mathrm{x}$ & \\
\hline & $\mathrm{A} \& W$ & $\mathrm{x}$ & & $\mathrm{x}$ & & $\mathrm{x}$ & & $\mathrm{x}$ & & $\mathrm{x}$ & & $\mathrm{x}$ & \\
\hline \multirow[t]{2}{*}{ All } & S\&S & 4.3 & & $\mathrm{x}$ & & $\mathrm{x}$ & & $\mathrm{x}$ & & 9.6 & & $\mathrm{x}$ & \\
\hline & $\mathrm{A} \& \mathrm{~W}$ & 31.7 & + & 14.2 & + & $\mathrm{x}$ & & 19.7 & + & 23.8 & + & 26.6 & + \\
\hline \multicolumn{14}{|l|}{ Wave } \\
\hline \multirow[t]{2}{*}{ N. Atlantic } & S\&S & $\mathrm{x}$ & & -26.4 & & $\mathrm{x}$ & & -20.3 & & 7.9 & & $\mathrm{x}$ & \\
\hline & $\mathrm{A} \& W$ & -6.5 & - & $\mathrm{x}$ & + & $\mathrm{x}$ & & $\mathrm{x}$ & + & 8.1 & + & $\mathrm{x}$ & \\
\hline \multirow[t]{2}{*}{ E. Africa, Indian Ocean } & S\&S & 9.5 & & $\mathrm{x}$ & & $\mathrm{x}$ & & $\mathrm{x}$ & & $\mathrm{x}$ & & 17.8 & \\
\hline & $\mathrm{A} \& W$ & $\mathrm{x}$ & - & $\mathrm{x}$ & & $\mathrm{x}$ & & 7.7 & + & $\mathrm{x}$ & & 13.4 & - \\
\hline \multirow[t]{2}{*}{ Japan, Korea, S. Chinese Sea } & S\&S & 10.9 & & $\mathrm{x}$ & & $\mathrm{x}$ & & $\mathrm{x}$ & & 15.8 & & $\mathrm{x}$ & \\
\hline & $\mathrm{A} \& W$ & 9.0 & - & $\mathrm{x}$ & & 12.0 & + & $\mathrm{x}$ & & 8.1 & - & $\mathrm{x}$ & \\
\hline \multirow[t]{2}{*}{ S. Atlantic, W. Africa } & S\&S & $\mathrm{x}$ & & $\mathrm{x}$ & & $\mathrm{x}$ & & $\mathrm{x}$ & & 13.8 & & $\mathrm{x}$ & \\
\hline & $\mathrm{A} \& W$ & $\mathrm{x}$ & & $\mathrm{x}$ & & 23.2 & + & $\mathrm{x}$ & & $\mathrm{x}$ & - & $\mathrm{x}$ & \\
\hline \multirow[t]{2}{*}{ N. Pacific } & S\&S & $\mathrm{x}$ & & $\mathrm{x}$ & & $\mathrm{x}$ & & $\mathrm{x}$ & & $\mathrm{x}$ & & 11.3 & \\
\hline & $\mathrm{A} \& W$ & $\mathrm{x}$ & & $\mathrm{x}$ & & $\mathrm{x}$ & & -26.4 & - & $\mathrm{x}$ & & $\mathrm{x}$ & - \\
\hline \multirow[t]{2}{*}{ S. Pacific, Antarctica } & S\&S & 6.5 & & $\mathrm{x}$ & & $\mathrm{x}$ & & $\mathrm{x}$ & & 10.2 & & $\mathrm{x}$ & \\
\hline & $\mathrm{A} \& W$ & 10.1 & + & 11.9 & + & 15.8 & + & $\mathrm{x}$ & & 15.6 & + & $\mathrm{x}$ & \\
\hline \multirow[t]{2}{*}{ All } & S\&S & 6.7 & & -10.6 & & $\mathrm{x}$ & & $\mathrm{x}$ & & 9.0 & & 8.2 & \\
\hline & $\mathrm{A} \& \mathrm{~W}$ & 3.1 & - & $\mathrm{x}$ & + & $\mathrm{x}$ & & $\mathrm{x}$ & & 8.5 & - & $\mathrm{x}$ & - \\
\hline
\end{tabular}

Table notes

* Season S\&S denotes the spring and summer season, April - September on the northern hemisphere and October - March on the southern hemisphere, and season A\&W denotes the complementary autumn and winter season.

* Numbers in the table show the percentage increase in the odds of weather-related incidents if wind speed or wave height increases by one standard deviation (see the text for computational details).

* Effects are reported only if significant at the (two-sided) 1\% level; insignificant effects are not reported and are indicated by "x"; "+" or "-" in the A\&W rows indicates that the effect of wind and wave is respectively stronger or weaker in autumn and winter. 
Table 2: Trend effects of wind and wave on the risk of weather-related incidents, per ship type and region

\begin{tabular}{|c|c|c|c|c|c|c|c|c|c|c|c|c|c|}
\hline \multirow[t]{2}{*}{ Region } & \multirow[t]{2}{*}{ Period } & \multicolumn{12}{|c|}{ Ship type } \\
\hline & & Cargo & & Dry bulk & & Container & & Tanker & & Passenger & & Other & \\
\hline \multicolumn{14}{|l|}{ Wind } \\
\hline \multirow[t]{2}{*}{ N. Atlantic } & 1 & 40.1 & & 20.1 & & $\mathrm{x}$ & & 31.3 & & $\mathrm{x}$ & & 35.1 & \\
\hline & 2 & 39.7 & - & 23.2 & + & $\mathrm{x}$ & & 27.8 & - & 30.3 & + & 29.7 & - \\
\hline \multirow[t]{2}{*}{ E. Africa, Indian Ocean } & 1 & $\mathrm{x}$ & & $\mathrm{x}$ & & $\mathrm{x}$ & & -19.7 & & $\mathrm{x}$ & & $\mathrm{x}$ & \\
\hline & 2 & 52.0 & + & $\mathrm{x}$ & & $\mathrm{x}$ & & $\mathrm{x}$ & + & $\mathrm{x}$ & & $\mathrm{x}$ & \\
\hline \multirow[t]{2}{*}{ Japan, Korea, S. Chinese Sea } & 1 & 19.9 & & $\mathrm{x}$ & & $\mathrm{x}$ & & $\mathrm{x}$ & & $\mathrm{x}$ & & $\mathrm{x}$ & \\
\hline & 2 & 44.7 & + & 22.6 & + & $\mathrm{x}$ & & 35.0 & + & 28.2 & + & 54.2 & + \\
\hline \multirow[t]{2}{*}{ S. Atlantic, W. Africa } & 1 & $\mathrm{x}$ & & $\mathrm{x}$ & & $\mathrm{x}$ & & $\mathrm{x}$ & & $\mathrm{x}$ & & $\mathrm{x}$ & \\
\hline & 2 & $\mathrm{x}$ & & $\mathrm{x}$ & & $\mathrm{x}$ & & $\mathrm{x}$ & & $\mathrm{x}$ & & $\mathrm{x}$ & \\
\hline \multirow[t]{2}{*}{ N. Pacific } & 1 & $\mathrm{x}$ & & $\mathrm{x}$ & & $\mathrm{x}$ & & $\mathrm{x}$ & & $\mathrm{x}$ & & 61.0 & \\
\hline & 2 & -25.5 & - & $\mathrm{x}$ & & $\mathrm{x}$ & & $\mathrm{x}$ & & $\mathrm{x}$ & & $\mathrm{x}$ & - \\
\hline \multirow[t]{2}{*}{ S. Pacific, Antarctica } & 1 & $\mathrm{x}$ & & $\mathrm{x}$ & & $\mathrm{x}$ & & $\mathrm{x}$ & & $\mathrm{x}$ & & $\mathrm{x}$ & \\
\hline & 2 & $\mathrm{x}$ & & $\mathrm{x}$ & & $\mathrm{x}$ & & $\mathrm{x}$ & & $\mathrm{x}$ & & $\mathrm{x}$ & \\
\hline \multirow[t]{2}{*}{ All } & 1 & 22.2 & & 11.7 & & $\mathrm{x}$ & & $\mathrm{x}$ & & $\mathrm{x}$ & & $\mathrm{x}$ & \\
\hline & 2 & 33.4 & + & 14.0 & + & $\mathrm{x}$ & & $\mathrm{x}$ & & 22.6 & + & 25.1 & + \\
\hline \multicolumn{14}{|l|}{ Wave } \\
\hline \multirow[t]{2}{*}{ N. Atlantic } & 1 & $\mathrm{x}$ & & $\mathrm{x}$ & & $\mathrm{x}$ & & $\mathrm{x}$ & & $\mathrm{x}$ & & $\mathrm{x}$ & \\
\hline & 2 & $\mathrm{x}$ & & -19.5 & - & $\mathrm{x}$ & & $\mathrm{x}$ & & 9.4 & + & 7.2 & + \\
\hline \multirow[t]{2}{*}{ E. Africa, Indian Ocean } & 1 & 7.5 & & $\mathrm{x}$ & & $\mathrm{x}$ & & $\mathrm{x}$ & & $\mathrm{x}$ & & 21.1 & \\
\hline & 2 & 13.5 & + & 4.6 & + & $\mathrm{x}$ & & $\mathrm{x}$ & & $\mathrm{x}$ & & $\mathrm{x}$ & - \\
\hline \multirow[t]{2}{*}{ Japan, Korea, S. Chinese Sea } & 1 & 10.6 & & $\mathrm{x}$ & & 10.7 & & $\mathrm{x}$ & & 12.3 & & $\mathrm{x}$ & \\
\hline & 2 & 9.7 & - & $\mathrm{x}$ & & $\mathrm{x}$ & - & $\mathrm{x}$ & & 8.4 & - & $\mathrm{x}$ & \\
\hline \multirow[t]{2}{*}{ S. Atlantic, W. Africa } & 1 & $\mathrm{x}$ & & $\mathrm{x}$ & & $\mathrm{x}$ & & $\mathrm{x}$ & & $\mathrm{x}$ & & $\mathrm{x}$ & \\
\hline & 2 & $\mathrm{x}$ & & $\mathrm{x}$ & & 13.6 & + & $\mathrm{x}$ & & $\mathrm{x}$ & & $\mathrm{x}$ & \\
\hline \multirow[t]{2}{*}{ N. Pacific } & 1 & $\mathrm{x}$ & & $\mathrm{x}$ & & $\mathrm{x}$ & & -33.5 & & $\mathrm{x}$ & & 12.9 & \\
\hline & 2 & $\mathrm{x}$ & & $\mathrm{x}$ & & $\mathrm{x}$ & & $\mathrm{x}$ & + & 21.9 & + & 13.9 & + \\
\hline \multirow[t]{2}{*}{ S. Pacific, Antarctica } & 1 & 5.1 & & 14.9 & & $\mathrm{x}$ & & $\mathrm{x}$ & & 19.9 & & $\mathrm{x}$ & \\
\hline & 2 & 10.8 & + & $\mathrm{x}$ & - & 11.4 & + & 9.4 & + & $\mathrm{x}$ & - & $\mathrm{x}$ & \\
\hline \multirow[t]{2}{*}{ All } & 1 & 6.1 & & $\mathrm{x}$ & & 9.2 & & $\mathrm{x}$ & & 8.5 & & 10.9 & \\
\hline & 2 & 5.4 & - & -6.8 & - & $\mathrm{x}$ & - & $\mathrm{x}$ & & 9.0 & + & 7.0 & - \\
\hline
\end{tabular}

Table notes

* Period 1 is for the years 1979-1991, and period 2 is for the years 1992-2008.

* This table is similar to Table 1, now for the risk in two periods instead of two seasons; "+" or "-" in the rows for period 2 indicates that the effect of wind and wave is respectively stronger or weaker in period 2. 
Table 3: Seasonal and trend effects of wind and wave on the risk of pollution incidents, per ship type and region

\begin{tabular}{|c|c|c|c|c|c|c|c|c|c|c|c|c|c|}
\hline \multirow[t]{2}{*}{ Region } & \multirow[t]{2}{*}{$\overline{\text { Period }}$} & \multicolumn{6}{|c|}{ Wind } & \multicolumn{6}{|c|}{ Wave } \\
\hline & & Cargo & & Dry bulk & & Tanker & & Cargo & & Dry bulk & & Tanker & \\
\hline \multicolumn{14}{|l|}{ Seasonal effects } \\
\hline \multirow[t]{2}{*}{ N. Atlantic } & S\&S & $\mathrm{x}$ & & 43.9 & & $\mathrm{x}$ & & $\mathrm{x}$ & & $\mathrm{x}$ & & -36.6 & \\
\hline & $\mathrm{A} \& W$ & 30.7 & + & 33.3 & - & 16.3 & + & $\mathrm{x}$ & & $\mathrm{x}$ & & $\mathrm{x}$ & + \\
\hline \multirow[t]{2}{*}{ E. Africa, Indian Ocean } & S\&S & $\mathrm{x}$ & & -48.1 & & $\mathrm{x}$ & & 11.1 & & $\mathrm{x}$ & & 10.4 & \\
\hline & $\mathrm{A} \& W$ & $\mathrm{x}$ & & $\mathrm{x}$ & + & $\mathrm{x}$ & & 9.9 & - & 11.7 & + & $\mathrm{x}$ & - \\
\hline \multirow[t]{2}{*}{ Japan, Korea, S. Chinese Sea } & S\&S & 33.0 & & $\mathrm{x}$ & & $\mathrm{x}$ & & 10.6 & & 11.4 & & $\mathrm{x}$ & \\
\hline & $\mathrm{A} \& \mathrm{~W}$ & 32.2 & - & $\mathrm{x}$ & & $\mathrm{x}$ & & 10.2 & - & $\mathrm{x}$ & - & $\mathrm{x}$ & \\
\hline \multirow[t]{2}{*}{ S. Atlantic, W. Africa } & S\&S & $\mathrm{x}$ & & $\mathrm{x}$ & & $\mathrm{x}$ & & $\mathrm{x}$ & & $\mathrm{x}$ & & $\mathrm{x}$ & \\
\hline & $\mathrm{A} \& W$ & $\mathrm{x}$ & & $\mathrm{x}$ & & $\mathrm{x}$ & & $\mathrm{x}$ & & $\mathrm{x}$ & & $\mathrm{x}$ & \\
\hline \multirow[t]{2}{*}{ N. Pacific } & S\&S & $\mathrm{x}$ & & $\mathrm{x}$ & & $\mathrm{x}$ & & $\mathrm{x}$ & & $\mathrm{x}$ & & $\mathrm{x}$ & \\
\hline & $A \& W$ & $\mathrm{x}$ & & $\mathrm{x}$ & & $\mathrm{x}$ & & $\mathrm{x}$ & & $\mathrm{x}$ & & $\mathrm{x}$ & \\
\hline \multirow[t]{2}{*}{ S. Pacific, Antarctica } & S\&S & $\mathrm{x}$ & & $\mathrm{x}$ & & $\mathrm{x}$ & & $\mathrm{x}$ & & $\mathrm{x}$ & & $\mathrm{x}$ & \\
\hline & $\mathrm{A} \& W$ & 78.1 & + & $\mathrm{x}$ & & $\mathrm{x}$ & & $\mathrm{x}$ & & $\mathrm{x}$ & & $\mathrm{x}$ & \\
\hline \multirow[t]{2}{*}{ All } & S\&S & 14.2 & & $\mathrm{x}$ & & $\mathrm{x}$ & & 5.8 & & $\mathrm{x}$ & & $\mathrm{x}$ & \\
\hline & $\mathrm{A} \& \mathrm{~W}$ & 30.1 & + & $\mathrm{x}$ & & 13.8 & + & 6.4 & + & $\mathrm{x}$ & & $\mathrm{x}$ & \\
\hline \multicolumn{14}{|l|}{ Trend effects } \\
\hline \multirow[t]{2}{*}{ N. Atlantic } & 1 & 33.4 & & 61.6 & & 18.8 & & $\mathrm{x}$ & & $\mathrm{x}$ & & -29.6 & \\
\hline & 2 & 33.1 & - & $\mathrm{x}$ & 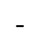 & 19.7 & + & $\mathrm{x}$ & & $\mathrm{x}$ & & $\mathrm{x}$ & + \\
\hline \multirow[t]{2}{*}{ E. Africa, Indian Ocean } & 1 & $\mathrm{x}$ & & $\mathrm{x}$ & & $\mathrm{x}$ & & 8.8 & & 17.0 & & 10.2 & \\
\hline & 2 & $\mathrm{x}$ & & $\mathrm{x}$ & & $\mathrm{x}$ & & 14.2 & + & 6.3 & - & $\mathrm{x}$ & - \\
\hline \multirow[t]{2}{*}{ Japan, Korea, S. Chinese Sea } & 1 & 45.5 & & $\mathrm{x}$ & & $\mathrm{x}$ & & 11.5 & & $\mathrm{x}$ & & $\mathrm{x}$ & \\
\hline & 2 & $\mathrm{x}$ & - & $\mathrm{x}$ & & $\mathrm{x}$ & & 8.7 & - & $\mathrm{x}$ & & $\mathrm{x}$ & \\
\hline \multirow[t]{2}{*}{ S. Atlantic, W. Africa } & 1 & $\mathrm{x}$ & & $\mathrm{x}$ & & $\mathrm{x}$ & & $\mathrm{x}$ & & $\mathrm{x}$ & & $\mathrm{x}$ & \\
\hline & 2 & $\mathrm{x}$ & & $\mathrm{x}$ & & $\mathrm{x}$ & & 11.2 & & $\mathrm{x}$ & & 14.8 & + \\
\hline \multirow[t]{2}{*}{ N. Pacific } & 1 & $\mathrm{x}$ & & $\mathrm{x}$ & & $\mathrm{x}$ & & $\mathrm{x}$ & & -70.6 & & $\mathrm{x}$ & \\
\hline & 2 & $\mathrm{x}$ & & $\mathrm{x}$ & & $\mathrm{x}$ & & $\mathrm{x}$ & & $\mathrm{x}$ & + & $\mathrm{x}$ & \\
\hline \multirow[t]{2}{*}{ S. Pacific, Antarctica } & 1 & $\mathrm{x}$ & & $\mathrm{x}$ & & $\mathrm{x}$ & & $\mathrm{x}$ & & $\mathrm{x}$ & & $\mathrm{x}$ & \\
\hline & 2 & 146.1 & + & $\mathrm{x}$ & & $\mathrm{x}$ & & 8.0 & + & $\mathrm{x}$ & & 11.6 & + \\
\hline \multirow[t]{2}{*}{ All } & 1 & 32.7 & & $\mathrm{x}$ & & $\mathrm{x}$ & & 8.1 & & $\mathrm{x}$ & & -15.1 & \\
\hline & 2 & 22.2 & - & $\mathrm{x}$ & & 14.4 & + & 4.8 & - & $\mathrm{x}$ & & $\mathrm{x}$ & + \\
\hline
\end{tabular}

Table notes

* This table is similar to Tables 1 and 2, now for the risk of pollution incidents instead of weather-related incidents.

* Results are shown for general cargo vessels, dry bulk ships, and tankers, because pollution incidents for the other ship types (container vessels, passenger ships, and other vessels) are too scarce to allow statistical analysis, see Table A.1. 
Table A.1: Number of incidents and non-incidents in the database, per ship type and region

\begin{tabular}{|c|c|c|c|c|c|c|c|c|}
\hline \multirow[t]{2}{*}{ Region } & \multirow[t]{2}{*}{ Incident type } & \multicolumn{7}{|c|}{ Ship type } \\
\hline & & Cargo & Dry bulk & Container & Tanker & Passenger & Other & All \\
\hline \multirow[t]{3}{*}{ N. Atlantic } & Non-incident & 610,915 & 162,267 & 524,669 & 264,624 & 71,838 & 202,828 & $1,837,141$ \\
\hline & Weather & 2,295 & 1,078 & 254 & 1,615 & 292 & 138 & 5,672 \\
\hline & Pollution & 178 & 52 & 24 & 283 & 27 & 18 & 582 \\
\hline \multirow[t]{3}{*}{ E. Africa, Indian Ocean } & Non-incident & 151,637 & 45,134 & 108,267 & 116,092 & 14,335 & 48,829 & 484,294 \\
\hline & Weather & 445 & 166 & 27 & 225 & 24 & 32 & 919 \\
\hline & Pollution & 23 & 17 & 3 & 56 & 3 & 3 & 105 \\
\hline \multirow[t]{3}{*}{ Japan, Korea, S. Chinese Sea } & Non-incident & 376,281 & 165,558 & 241,539 & 232,030 & 46,139 & 91,595 & $1,153,142$ \\
\hline & Weather & 1,603 & 374 & 63 & 738 & 120 & 78 & 2,976 \\
\hline & Pollution & 185 & 48 & 18 & 216 & 3 & 8 & 478 \\
\hline \multirow[t]{3}{*}{ S. Atlantic, W. Africa } & Non-incident & 172,711 & 38,095 & 99,958 & 80,969 & 14,133 & 53,739 & 459,605 \\
\hline & Weather & 249 & 238 & 22 & 224 & 20 & 15 & 768 \\
\hline & Pollution & 12 & 18 & 4 & 35 & 2 & 1 & 72 \\
\hline \multirow[t]{3}{*}{ N. Pacific } & Non-incident & 282,290 & 125,898 & 388,809 & 207,076 & 26,541 & 80,534 & $1,111,148$ \\
\hline & Weather & 189 & 173 & 32 & 209 & 20 & 25 & 648 \\
\hline & Pollution & 15 & 11 & 5 & 39 & 3 & 2 & 75 \\
\hline \multirow[t]{3}{*}{ S. Pacific, Antarctica } & Non-incident & 129,312 & 70,077 & 102,311 & 39,747 & 23,102 & 57,915 & 422,464 \\
\hline & Weather & 157 & 107 & 21 & 145 & 45 & 14 & 489 \\
\hline & Pollution & 11 & 15 & 1 & 29 & 8 & 2 & 66 \\
\hline \multirow[t]{7}{*}{ All } & Non-incident & $1,723,146$ & 607,029 & $1,465,553$ & 940,538 & 196,088 & 535,440 & $5,467,794$ \\
\hline & Weather & 4,938 & 2,136 & 419 & 3,156 & 521 & 302 & 11,472 \\
\hline & $\% A \& W$ & 63.6 & 58.7 & 60.1 & 61.6 & 52.4 & 58.3 & 61.3 \\
\hline & \% Period 2 & 40.5 & 50.5 & 65.4 & 34.1 & 61.0 & 66.6 & 43.1 \\
\hline & Pollution & 424 & 161 & 55 & 658 & 46 & 34 & 1,378 \\
\hline & $\%$ A \& W & 58.7 & 52.2 & 50.9 & 54.3 & 41.3 & 52.9 & 54.8 \\
\hline & \% Period 2 & 54.7 & 53.4 & 76.4 & 48.9 & 69.6 & 82.4 & 53.8 \\
\hline
\end{tabular}

Table notes

* The table reports database counts of weather-related and pollution incidents and of non-incidents, for the years 1979-2008.

* The A \& W season is October - March on the northern hemisphere, and April - September on the southern hemisphere.

* Period 2 is for the years 1992-2008. 